\title{
A THEORY OF THE PATHOGENESIS OF RHEUMATOID ARTHRITIS
}

\author{
BY \\ ALLAN D. WALLIS \\ From the Ayer Clinical Laboratory, Pennsylvania Hospital, Philadelphia, U.S.A.
}

\begin{abstract}
"Another assumed cause of origin for these proliferative joint changes (in rheumatoid arthritis) is that an irritant is produced as the result of 'faulty metabolism ', i.e. it is assumed that, on account of some supposed abnormality in physiological processes of certain tracts or organs of the body, or as a result of abnormal cellular changes, a soluble irritant of some unknown sort is produced, which for some unexplained reason selects the joint cavities and epiphyses of the bones as the site of most marked activity. . . . Although with the present state of physiological and chemical knowledge the actual demonstration of such an irritant is impossible, the clinical and pathological facts make the assumption of its existence plausible, and we believe that the etiological factor in the production of many of these joint lesions is explicable on these grounds."
\end{abstract}

(Nichols and Richardson, 1909.)

It is with some hesitation that one advances a new theory, particularly in regard to rheumatoid (atrophic) arthritis, which has already been the subject of so much speculation. However, recent observations of Wallis and Horvath (1949) on the tissue-fixation of antibodies may provide a missing link worthy of consideration in the pathogenesis of this type of arthritis. Among the various kinds of arthritis there may be others whose pathogenesis is the same as that of typical adult rheumatoid arthritis, but to avoid unnecessary complications the present discussion is restricted to this disease in its classical form. A fairly symmetrical involvement of the proximal interphalangeal finger joints and a disease duration of one year have been adhered to as minimal requirements in selecting patients for study.

There is general agreement that circulating antibodies are capable of becoming temporarily attached to tissue cells. An important site of this fixation is believed to be the walls of blood vessels, especially arterioles. The amounts of tissue-fixed and circulating antibody, while they are not necessarily equal, are known to rise and fall together, in a so-called dynamic equilibrium. The purpose of tissuefixation of antibody is presumably one of temporary storage.

This mechanism, however, has unfortunate side-effects, of which the best known are the sensitivity reactions classifiable under the broad heading of anaphylaxis. These reactions, which vary with the organ and the species, are believed to represent tissue response to the union of tissue-fixed antibody and homologous circulating antigen. While sensitivity reactions may play a part in producing the carditis 
which sometimes accompanies severe rheumatoid arthritis (Wallis, 1948), it is with a different effect of tissue-fixed antibody that the present communication is concerned.

\section{Tissue-Fixed Antibody and Vasoconstrictor Responsiveness}

More than twenty years ago Dietrich and Nordmann $(1928,1929)$ described the influence of intensive immunization on the vascular response to epinephrine in rabbits. With the mesentery under a microscope they saw that the contraction of the arterioles caused either by the local application or by the intravenous injection of this drug was both weaker and briefer in hyper-immunized rabbits than in non-immune controls. Likewise, the rise in the carotid arterial blood pressure caused by the intravenous injection of epinephrine was smaller in the immunized animals. Dietrich and Nordmann explained these changes on the assumption that immunization modifies the irritability of the central nervous system.

Wallis and Horvath (1949) have recently noted comparable alterations of vascular response in human subjects. Measuring the rise in systolic blood pressure produced by the intravenous injection of $0.01 \mathrm{mg}$. epinephrine, they found that the vasoconstrictor response to this stimulus is apt to be impaired in the presence of excessive numbers of circulating antibodies and therefore, presumably, excessive numbers of tissue-fixed antibodies. The conclusion was reached that tissue-fixed antibodies in large numbers are able, by their physical presence, to impede the rapid contraction of the arteriolar constrictor muscles. This effect is independent of the serologic specificity of the antibodies. It is probable that antibodies in moderate amounts, or perhaps even in small (i.e. "normal ") amounts, exert the same influence to a lesser degree, although the effect was demonstrable by this method only in the presence of an excess of antibodies.

Among the subjects with an impaired blood-pressure response to epinephrine, were patients with active severe typical rheumatoid arthritis. Such patients have been shown (Wallis, 1950) to present electrophoretic evidence of excessive numbers of circulating antibodies. The blood-pressure response to epinephrine suggests that tissue-fixation of the antibodies of rheumatoid arthritis interferes with the contraction of arteriolar smooth muscle. There exists a strong possibility that this interference with vasoconstriction may in turn influence the subsequent course of the disease. If this is so, tissue-fixed antibody becomes a central factor of major importance in this type of arthritis.

\section{Predisposing and Precipitating Factors}

Rheumatoid arthritis is known to be more common in females and in temperate climates, and has been observed to follow emotional shocks (Smith, 1932; Burt and others, 1938; Cobb and others, 1939; Halliday, 1942) and acute infections such as gonorrhoea or tonsillitis (Cecil, 1943; Hench and Boland, 1946). With the exception of the precipitating effect of acute infections, these oddly-assorted factors have a common ground in their more or less obvious ability to stimulate 
contraction of the peripheral arterioles. The following discussion of this common ground is based on the principle (Clark and Clark, 1943) that the peripheral blood flow is controlled mainly by the calibre of the arterioles and small arteries, the capillaries reflecting more or less passively the changes which occur in the arterioles.

As far as the effect of cold climates (or, more important, changeable climates) is concerned, it is well known that external cold is a stimulus of peripheral vasoconstriction. The vasoconstrictor action of emotional states is less obvious. By measurements of local blood flow or of finger-tip temperatures it has been shown that the peripheral blood vessels become constricted as a result of sudden loud noises (Hertzman and Dillon, 1939), moods of anxiety (Neumann and others, 1944), discussion of unpleasant topics (Patterson and others, 1943), concentration on problems in arithmetic (Mittelmann and Wolff, 1939), or of being told that one is going to receive an injection (Naide and others, 1945). The rapidity of most of these responses is indicative of the existence of a neural mechanism for the mediation of peripheral vasoconstriction of psychic origin.

\section{Superficial Peripheral Vascular Tone}

The role of sex in vasoconstriction also needs explanation. Naide and Saÿen $(1944,1945)$ measured the rate of fall of finger-tip temperature in a room at $20^{\circ} \mathrm{C}$. (vasoconstriction) and its rate of rise upon the application of heat to the trunk (vasodilation). They interpreted ready constriction and reluctant dilation as indicative of a naturally high vascular tone, which they found more frequently present in women than in men. Applying this test to sufferers from rheumatoid arthritis, Naide and others (1945) found that all such patients examined belonged to the high vascular-tone group. They related this to the predilection of rheumatoid arthritis for the female, and felt that the high vascular tone antedated the disease and "may be one of the basic factors in predisposing persons to rheumatoid arthritis".

Naide and Saÿen made their observations in Philadelphia. When Burch and others (1947) used the same procedure in New Orleans in the summer they found a generally lower incidence of high vascular tone in normal subjects, but agreed that it is more common in women. Naide (1948) has subsequently found a lower incidence of high vascular tone in Philadelphia in the summer months. Since the influence of cold may be necessary for its demonstration, it would be more accurate to speak of this state as a potentially high peripheral vascular tone. Some believe it to be prerequisite to the development of rheumatoid arthritis.

It should also be noted that surface temperature is a measure of blood flow in skin and subcutaneous tissue but not necessarily of flow in deeper vessels. In the course of measurements of intra-articular temperature, Horvath and Hollander (1949) have obtained data which indicate that the application of heat or cold over the knee has an effect on vessels supplying that joint which is opposite to the effect on the skin vessels. Cold raised the joint temperature and heat lowered it. This implies a reflex shunting of arterial blood between superficial and deep vessels, presumably through communicating branches. Such a mechanism would permit 
a shifting of arterial blood toward or away from the surface as an aid in the dissipation or conservation of body heat. The presumed basic factor in rheumatoid arthritis may therefore be more fully described as a potentially high superficial peripheral vascular tone.

It is evident that, with the exception of the precipitating effect of acute infections, the background factors mentioned as favouring the development of rheumatoid arthritis will also favour the constriction of superficial peripheral arterioles. The key may lie in this exception. There is no reason to suppose that acute infections are followed by peripheral vasoconstriction, but it has been noted above that tissuefixation of post-infectional antibodies could oppose the action of vasoconstrictor muscles through a "braking" action, and so cause them to tire readily. This provides a common ground for all the predisposing agencies, namely a capacity for decreasing the responsiveness of superficial peripheral vasoconstrictor muscles either through over-stimulation or by offering resistance to their contraction.

\section{Diminished Responsiveness of Vasoconstrictors}

Support for the concept that patients with rheumatoid arthritis have an impairment in the responsiveness of their peripheral vasoconstrictors may be found in the finger-tip temperature data of Woodmansey and others (1938) and of Pemberton and Scull (1938). In addition to the low initial temperature characteristic of a high vascular tone, the subjects of these reports showed a fall in temperature smaller than normal in response to stimulation by cold.

To suggest that rheumatoid arthritis results from diminished responsiveness of the constrictor musculature of superficial peripheral arterioles raises questions which cannot be fully answered until more is known of the physiology and chemistry of smooth muscle. How can the cold hands of the rheumatoid arthritic be reconciled with a defect in vasoconstrictor responsiveness? The defect evidently does not extend to the point of exhaustion and relaxation and hence to vasodilation. An answer is provided by the conception that smooth muscle expends little or no energy in maintaining tension, the principal expenditure being made in effecting increases in tension (Starling, 1945). Effortless maintenance of a given tension brings to mind the analogy of a ratchet. A more physiologic mechanism is sugested by the description of smooth muscle by Bozler (1936) as plastic, rather than elastic like voluntary muscle, in the sense that its fibres can regain their initial tension after a change in length. In the light of this description, arteriolar constrictors could maintain their tone-even a high tone-and at the same time be unable to give a full response when stimulated.*

* The diminished superficial peripheral-vasoconstrictor responsiveness of the rheumatoid arthritic is not attributable simply to his higher initial vascular tension, which might be expected to have used up a part of the potential constrictor response to a given stimulus. In the course of direct microscopic observations of blood vessels in transparent chambers installed in rabbits' ears, Clark (1947) has repeatedly noted that the degree of tension of an arteriole has no significant influence on its ability to contract in response to a standard stimulus. For example, with the ear warm and the animal awake, a given arteriole may have an inside diameter of $80 \mu$. When the animal is prodded with a finger all the arterioles contract, this particular one narrowing to $40 \mu$. When the ear is cold, the lumen of the same vessel might have a resting diameter of $40 \mu$, which upon similar prodding would be reduced to zero. This is in accord with the principle that a normal smooth-muscle fibre can regain its initial tension after a change in length. 
Diminished responsiveness is of course a manifestation of fatigue, a term which has thus far been avoided in the present discussion because of the connotations of exhaustion and relaxation which it has acquired through association with nerve and voluntary muscle. Although direct evidence that smooth muscle is capable of fatigue appears to be lacking, there is presumably a limit to its responsiveness. Fatigue implies a depletion of reserve sources of biochemical energy, and this in turn presupposes an attempt to replenish the depleted stores. Prolonged overstimulation, particularly against resistance as offered by tissue-fixed antibodies, is no doubt uncommon in smooth muscle, which may as a consequence be illequipped to deal with the problem of restoring exhausted reserves. Since the functional consequences of exhaustion are not the same in smooth as in voluntary muscle, the term " fatigue" will be used hereafter in quotation marks.

\section{Relation of Vasoconstrictor Dysfunction to Synovitis}

Granting that sufferers from rheumatoid arthritis have a diminished responsiveness to vasoconstrictor stimuli, how can this produce a synovitis? Vaubel (1933) showed that synovial cells have as a specific function the synthesis of a lubricating material, since identified by Meyer and others (1939) as the mucopolysaccharide hyaluronic acid. The development of functional equivalents of synovial cells and synovial fluid in pseudarthroses and arthroplasties suggests that the specific stimulus for the accelerated production of this material is motion, or friction. Since the subcutaneous nodules of rheumatoid arthritis occur at sites of prolonged friction over bony prominences, and since hyaluronic acid occurs also in subcutaneous tissue (Meyer and Chaffee, 1941), it may be presumed that in these locations the rate of hyaluronic acid synthesis may be stimulated to approach that normally present in joints. Perhaps in rheumatoid arthritis a metabolite of vasoconstrictor "fatigue " is liberated into the arteriolar lumen and, being transported elsewhere, happens to find, in cells actively engaged in the synthesis of hyaluronic acid, biochemical circumstances receptive to its action.

Transport from superficial arterioles to synovial cells could well occur by way of the intercommunications between superficial and deep vessels already mentioned, particularly since this would be the direction of flow in the presence of external cold. The relative immunity of the distal interphalangeal joint in rheumatoid arthritis suggests the possibility that such communicating vessels may be lacking in the vicinity of this joint, their function being perhaps taken over by arteriovenous anastomoses. These are structures which are superficially situated, and which open in response to cold below $10^{\circ} \mathrm{C}$., permitting direct transfer of blood from small arteries to veins. They have been shown by Grant and Bland (1931) to be most abundant in the distal phalanx.

The steps in the gap between vasoconstrictor "fatigue " on one hand, and metabolic derangement in a synovial cell on the other, are difficult to visualize in the present state of biochemical knowledge. It may be assumed that smooth muscle tries to restore its reserves by excessive production of one or more of the (phosphorylating?) enzymes concerned in energy transfer, and that such an enzyme 
happens to find a receptive substrate at some stage in the actively progressing step-wise synthesis of hyaluronic acid. If one supposes, for example, that a phosphate group is unexpectedly attached to a precursor of hyaluronic acid when enzymatic means are not at hand for removing it, then a profound disturbance in the internal economy of the host cell would naturally follow.

Such a perversion of the synthesis of hyaluronic acid is presumed to occur intermittently and in relatively few synovial cells at any one time. It appears to result in the release of two abnormal substances: an antigen (responsible for the patient's antibodies) and an irritant (responsible for his local signs and symptoms), the antigen being derived presumably from a perverted precursor stage of hyaluronic acid and the irritant being a break-down product of the deranged synovial cell's own protoplasm, analogous to necrosin (Menkin, 1943).*

By analogy with necrosin, the irritant would be a globulin. Bauer and others (1933) have shown that globulin molecules deposited interstitially are removable only by lymphatics, and by them poorly at best. Since the local lymphatics are known (Kuhns, 1933) to be occluded in rheumatoid arthritis, it is not surprising that the local symptoms are of long duration. The capillary hyperaemia responsible for the local heat is part of the inflammatory reaction and is not inconsistent with arteriolar hypertonus.

\section{Rheumatoid Arthritis as a Self-Perpetuating Disease}

A vicious circle whereby rheumatoid arthritis once established may tend to perpetuate itself is presented schematically in the accompanying Figure. From this standpoint the wonder is not that rheumatoid arthritis is a chronic disease, but rather that remissions ever occur. That they do occur may be taken to mean that tissue-fixed antibody alone is not capable of causing vasoconstrictor " fatigue ", but needs vasoconstrictor stimuli in addition.

The central features of the figure have already been discussed. Some of the items at its periphery call for further consideration. Let us begin with jaundice and cortisone on the right hand margin and proceed clockwise.

The beneficial influence of intercurrent obstructive jaundice upon rheumatoid arthritis has been well established by Hench (1940). The sometimes dramatic speed with which this benefit occurs suggests that its mechanism differs from that of other beneficial agencies, such as pregnancy, and implies a rapid neutralizing or detoxifying effect. It is known (Neurath and others, 1944) that synthetic detergents are capable of denaturing some proteins. Recalling that bile salts are detergents,

* Menkin injected turpentine into the pleural cavities of dogs. Sulfate fractionation of the ensuing sterile exudate yielded a number of protein degradation products recognizable by their physiologic activity. Since they were not originally present and had not been introduced, they were presumably derived from cellular proteins. One of them, a euglobulin, is a tissue irritant which Menkin named necrosin. None of these fractions is antigenic in the animal which produces them. This is presumably because they do not differ sufficiently from native proteins to be recognized as foreign by the antibody-producing apparatus of the host. The apparent inability of the antibodies of the sufferer from rheumatoid arthritis to relieve his symptoms is further evidence that the irritant has not aroused the antibodies, i.e. like other breakdown products of tissue proteins it is not antigenic. The irritant and the antigen in this disease are therefore regarded as separate substances. 
and assuming that the irritant here postulated is less stable than normal proteins, the jaundice effect becomes understandable. On the basis of the Figure, the remission induced by jaundice would be long or short depending on the period of time that elapsed before vasoconstrictor "fatigue" again reached a critical threshold and set in motion the chain of events leading to the release of fresh irritant.

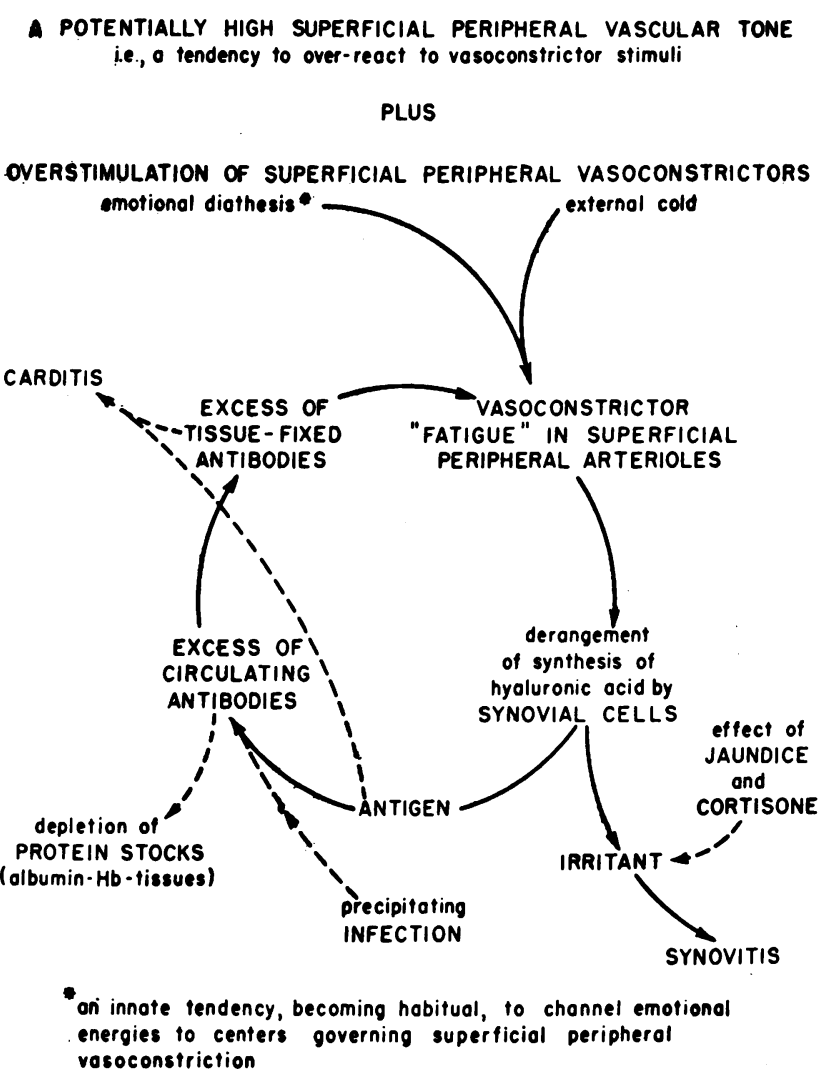

FIGURE.-Theoretical inter-relationships between major factors in rheumatoid arthritis. Solid lines indicate inter-relationships present in all cases.

The rapidity of the symptomatic relief afforded by cortisone (Hench and others, 1949) suggests that it too may have a surface action upon an irritant substance. The return of symptoms soon after the withdrawal of this drug implies that its detoxifying action is more transient, i.e. more readily reversible, than that of jaundice.

The precipitating effect of acute infections is obviously dependent on the patient's physiologic and psychologic background. Only when the stage is otherwise set can post-infectional antibodies act as the last straw and start the circle in motion. This concept sheds light on those cases of rheumatoid arthritis which merge insensibly with antecedent rheumatic fever and have sometimes been cited to show 
that these diseases are merely different aspects of the same pathologic process. There is, however, a large body of clinical, bacteriologic, and serologic evidence which indicates that rheumatic fever is caused by the haemolytic streptococcus, whereas the case for this organism as the cause of rheumatoid arthritis rests principally on the fact that it is strongly agglutinated by the sera of many rheumatoid arthritics. This phenomenon has been explained (Wallis, 1947) as a non-specific enhancement of the action of normally-present agglutinins. It therefore appears preferable to regard acute rheumatic fever as a separate entity which is occasionally in a position to precipitate rheumatoid arthritis.

Depletion of such protein stocks as plasma albumin, haemoglobin and tissue proteins generally, for the sake of producing an excess of antibodies which in this case serve no apparent purpose has been discussed elsewhere (Wallis, 1950).

It has been suggested (Wallis, 1948) that the rheumatic-type carditis which is occasionally the cause of death in patients with rheumatoid arthritis represents a response to the union of tissue-fixed antibody and homologous antigen, the latter being distinct from the antigen of actual rheumatic fever.

\section{Psychosomatic Background}

The emotional diathesis referred to in the Figure seems to be another important missing link in the pathogenesis of rheumatoid arthritis. There are countless individuals with a potentially high superficial peripheral vascular tone who are subjected to external cold, emotional shocks, and acute infections without developing rheumatoid arthritis. This has given rise to the suspicion that the " $X$ " factor in the pathogenesis of this disease is an infective agent, known or unknown. It seems preferable to resolve this question by analogy with peptic ulcer, in which it is generally agreed that a functional disturbance of psychic origin leads to organic changes. There are many people who endure emotional stresses without acquiring a peptic ulcer. This is presumably because they have not the "ulcer temperament". The observations of Mittelmann and Wolff (1942) indicate that unless a person is capable of aggressive hostility as a dominant emotion he is not eligible for peptic ulcer. In the same way it may be supposed that a particular temperamental background is necessary before a person is eligible for rheumatoid arthritis. Such a background would involve, as suggested in the figure, a tendency to canalize emotional energies to those cerebral centres which mediate superficial peripheral vasoconstriction, as part of an overdeveloped " fight or flight" mechanism. By analogy with the acquisition of mental or physical skills, one can see how repetition would render the use of these pathways habitual, until with a sufficient degree of habituation a high level of superficial peripheral vasoconstriction could be maintained in the absence of external cold. This is the sort of situation Darwin (1897) had in mind when he wrote that " serviceable actions become habitual in association with certain states of the mind, and are performed whether or not of service in each particular case." The existence of a temperament which predisposes to rheumatoid arthritis has been proposed by Halliday (1943), who compared the personalities subject to rheumatoid arthritis with those subject to peptic ulcer and found the 
former self-effacing and the latter self-assertive. In our experience this temperament is more characteristic of the male than of the female rheumatoid arthritic.

The foregoing discussion is in accord with the viewpoint that rheumatoid arthritis is a psychosomatic disease-one in which the changes are functional in the beginning and organic in the end. As such it is not to be confused with "psychogenic rheumatism" (Hench and Boland, 1946), which is a manifestation of hysteria and does not produce the organic changes of true rheumatoid arthritis.

\section{Summary}

Any explanation of rheumatoid (atrophic) arthritis must take into account its predilection for females, for " temperate" climates, and for synovial tissues, its tendency to be symmetrical and to be accompanied by cold hands, the predisposing effect of emotional shocks, and the precipitating effect of acute infections.

The pathogenesis of this disease is re-examined in the light of recent observations which suggest that tissue-fixed antibodies oppose the contraction of arteriolar vasoconstrictor muscles by a " brake-like" action.

It is pointed out that the agencies which favour the development of rheumatoid arthritis also have a tendency, with the aid of a naturally high vascular tone (more common in women), to tire superficial peripheral vasoconstrictor muscles, either through over-stimulation or by offering resistance to their action. The theory is advanced that a metabolite of the resultant smooth muscle " fatigue " interferes with the synthesis of the mucopolysaccharide hyaluronic acid by synovial cells, leading to the production of two abnormal substances, an irritant responsible for the patient's symptoms, and an antigen which, by arousing antibodies, completes a vicious circle whereby the disease process perpetuates itself.

\section{REFERENCES}

Bauer, W., Short, C. L., and Bennett, G. A. (1933). J. exp. Med., 57, 419.

Bozler, E. (1936). Cold Spr. Harb. Symp. quant. Biol., 4, 260.

Burch, G. E., Myers, H. L., Porter, R. R., and Schaffer, N. (1947). Bull. Johns Hopk. Hosp., 80, 1.

Burt, J. B., Gordon, R. G., and Brown, A. R. (1938). In "A Survey of Chronic Rheumatic Diseases ", ed. R. G. Gordon, p. 137 . Oxford Univ. Press, London.

Cecil, R. L. (1943). “A Aextbook of Medicine”, 6th ed., p. 1296. Saunders, Philadelphia.

Clark, E. R. (1947). Personal communication.

-, and Clark, E. L. (1943). Amer. J. Anat., 73, 215.

Cobb, S., Bauer, W., and Whiting, I. (1939). J. Amer. med. Ass., 113, 668.

Darwin, C. R. (1897). "The Expression of the Emotions in Man and Animals ", p. 27. Appleton, New York.

Dietrich, A., and Nordmann, M. (1928). Krankheitsforschung., 6, 217.

- — - (1929). Ibid., 7, 321.

Grant, R. T., and Bland, E. F. (1931). Heart, 15, 385.

Halliday, J. L. (1942). Proc. R. Soc. Med., 35, 455.

(1943). Lancet, 2, 692.

Hench, P. S. (1940). Med. Clin. N. Amer., 24, 1209.

- , and Boland, E. W. (1946). Ann. intern. Med., 24, 808.

- Kendall, E. C., Slocumb, C. H., and Polley, H. F. (1949). Proc. Mayo Clin., 24, 181.

Hertzman, A. B., and Dillon, J. B. (1939). Amer. J. Physiol., 127, 671.

Horvath, S. M., and Hollander, J. L. (1949). J. clin. Invest., 28, 469.

Kuhns, J. G. (1933). Arch. Surg., Chicago, 27, 345.

Menkin, V. (1943). Arch. Path., 36, 269.

Meyer, K., and Chaffee, E. (1941). J. biol. Chem., 138, 491.

-, Smyth, E. M., and Dawson, M. H. (1939). Ibid., 128, 319. 
Mittelmann, B., and Wolff, H. G. (1939). Psychosom. Med., 1, 271.

- (1942). Ibid., 4, 5.

Naide, M. (1948). Personal communication.

—, and Sayen, A. (1944). Amer. J. med. Sci., 207, 606.

- - (1945). Ibid., 209, 478.

$\longrightarrow,-$, and Comroe, B. I. (1945). Arch. intern. Med., 76, 139.

Neumann, C., Lhamon, W. T., and Cohn, A. E. (1944). J. clin. Invest., 23, 1.

Neurath, H., Greenstein, J. P., Putnam, F. W., and Erickson, J. O. (1944). Chem. Rev., 34, 157.

Nichols, E. H., and Richardson, F. L. (1909). J. med. Res., 21, 149.

Patterson, R. M., Craig, J. B., Waggoner, R. W., and Freyberg, R. (1943). Amer. J. Psychiat., 99, 775.

Pemberton, R., and Scull, C. W. (1938). In "A Survey of Chronic Rheumatic Diseases", p. 107. Oxford Univ. Press, London.

Smith, M. (1932). New Engl. J. Med., 206, 211.

Starling, E. H. (1945). " " Principles of Human Physiology ", 9th ed., ed. C. L. Evans, p. 159. Churchill, London; Lea and Febiger, Philadelphia.

Vaubel, E. (1933). J. exp. Med., 58, 85.

Wallis, A. D. (1947). Amer. J. med. Sci., 213, 94.

- (1948). Annals of the Rheumatic Diseases, 7, 97.

(1950). Ann. intern. Med., 32, 63.

- and Horvath, S. M. (1949). J. appl. Physiol., 1, 856.

Woodmansey, A., Collins, D. H., and Ernst, M. M. (1938). Lancet, 2, 1350.

\section{Une Théorie sur la Pathogénie de l'Arthrite Rhumatismale}

\section{RÉSUMÉ}

Toute explication de l'arthrite rhumatismale (atrophique) doit tenir compte de sa prédilection pour les femmes, pour les climats "tempérés", et pour les membranes synoviales; de sa tendance à la symétrie et à l'association avec des mains froides; de l'effet prédisposant du choc émotionnel; et de l'effet précipitant des infections aiguës.

La revue de la pathogénie de cette maladie à la lumière des observations récentes suggère que des anticorps fixés par les tissus s'opposent à la contraction des muscles vasoconstricteurs des artérioles comme s'il la freinaient.

On signale que les agents qui favorisent le développement de l'arthrite rhumatismale ont aussi tendance-renforcée par le tonus vasculaire naturellement élevé (plus communément chez les femmes)-à fatiguer les muscles vasoconstricteurs périphériques superficiels par une stimulation exagérée ou bien par la résistance à leur action. On avance une théorie selon laquelle un métabolite provenant de la "fatigue " du muscle lisse empêcherait la synthèse de l'acide hyaluronique mucopolysaccharide par les cellules synoviales, ce qui menerait à la production de deux substances anormales: d'un irritant donnant naissance aux symptômes et d'un antigène qui, en provoquant la formation des anticorps, fermerait le cercle vicieux et éterniserait ainsi le processus morbide.

\section{Una Teoría Sobre la Patogenía de la Artritis Reumatoide}

\section{RESUMEN}

Toda explicación de la artritis reumatoide (atrófica) debe tener cuenta de su predilección por las mujeres, por los climas "templados", y por las membranas sinoviales; de su tendencia a la simetría y a la asociación con manos frías; del efecto predisponente del choque emocional; y del efecto precipitante de las infecciones agudas.

La revista de la patogenía de esta enfermedad a la luz de observaciones recientes sugiere que los anticuerpos fijados por los tejidos se oponen a la contracción de los músculos vasoconstrictores de las arteriolas como si la frenasen.

Se señala que los agentes que favorecen el desarrollo de la artritis reumatoide tienen también tendencia - con la ayuda del tono vascular naturalmente elevado (más común en las mujeres) a cansar los músculos vasoconstrictores periféricos superficiales por una estimulación exagerada o por una resistencia a su acción. Se propone una teoría según la cual un metabólito procediente de la "fatiga " del músculo liso impide la síntesis del ácido hialurónico mucopolisacarido por las células sinoviales, lo que causa la producción de dos substancias anormales: un irritante que causa los síntomas del enfermo y un antígeno que provoca la formación de anticuerpos, completando así el círculo vicioso y perpetuando el proceso mórbido. 